\title{
Modernism Romanced: Imaginary Geography in Jerzy Żuawski’s The Lunar Trilogy
}

\author{
Łukasz Wodzyński
}

At the end of the nineteenth century, the slowly coalescing genre of science fiction suffered the same schizophrenia that affected the social imaginary of this historical period. For some, it was a time when Europe celebrated its greatness and eagerly anticipated a still brighter future, despite all the signs and portents of a large-scale crisis: economic downturns, social unrests, the rise of nationalisms, and military buildup. From this perspective, it was la belle époque, "the beautiful era." For others-primarily but not exclusively in intellectual and artistic circles-the last two decades of the nineteenth century were anything but celebratory. Segments of the educated elite perceived marks of degeneration in all spheres of life-politics, biology, morality, social practices, and culture-suggesting to them that under the pressure of accelerating modernity the human subject was gradually being stripped of spiritual, intellectual, artistic, and moral qualities. Hence the second designation of the period as the end of an era and, in a deeper sense, the end of times: fin de siècle. ${ }^{2}$

Like all forms of popular culture, past and present, scientific and utopian romances written at the time were closely attuned to contemporary social and cultural sensibilities. Hopeful utopias like Edward Bellamy's Looking Backward, 2000-1887 (1887) and William Morris' News from Nowhere (1890) have their dark counterparts in such somber visions as those of Richard Jefferies' After London (1885), Didier de Chousy's Ignis (1883), or H.G. Wells's scientific romances, in which humanity balances between utopian and catastrophic scenarios of its distant and not-too-distant future.

As a work drawing on utopian, scientific, and adventure romances, Jerzy Żuławski's The Lunar Trilogy shares this dual outlook on the historical

I would like to thank Harriet Murav and my two anonymous reviewers for their comments and suggestions on the early drafts of this article.

1. See, for example, Eric J. Hobsbawm, The Age of Empire: 1875-1914 (New York, 1987), 46-55. For a more detailed social and cultural account of the Belle Époque, see also Charles Rearick, Pleasures of the Belle Époque: Entertainment and Festivity in Turn-of-the-Century France (New Haven, 1988).

2. There exist numerous overviews of the pessimistic and apocalyptic sensibility characterizing late-nineteenth-century Europe. For an excellent and now classic study of the subject, see Jean Pierrot, The Decadent Imagination: 1880-1900 (Chicago, 1981). For the Polish reception of decadent and catastrophic ideas, see: Teresa Walas, Ku otchtani: Dekadentyzm w literaturze polskiej, 1890-1905 (Kraków, 1986); Maria Podraza-Kwiatkowska, Somnambulicy, dekadenci, herosi: Studia i eseje o literaturze Młodej Polski (Kraków, 1985), as well as her other works on the period; and Justyna Miklaszewska, "Katastrofizm w twórczości Jerzego Żuławskiego.” Rocznik Komisji Historycznoliterackiej 25 (1988): 83-110. 
trajectory of western civilization. ${ }^{3}$ What makes these books unique when compared to other novelistic experiments of the period-such as Wacław Berent's Próchno (1901) and Karol Irzykowski's Pałuba (1903)-is that they interweave two antagonistic cultural modes: popular romance in its scientific and travel-adventure varieties, and modernist poetic reflection on the mythological and transcendental foundations of human history. In doing so, the trilogy seeks to reevaluate the mythical and archetypal treasury of western culture-indeed, Northrop Frye calls romance the secular scripture-but also produces a highly readable treatise on the role of individuals in society. ${ }^{4}$

Such a hybrid between early modernism and popular romance is unusual, because the two cultural modes emblematize opposing approaches to modernity, a catastrophic and positivist one, respectively. In the present article I analyze how and when these two modes reinforce and contradict one another in Żuławski's opus. I also attempt to define what kind of model this fusion offers for the early modernist novel and what "dissonance of existence," to use Lukács's famous formula, prompted such an unusual experiment on Żuławski's part. ${ }^{5}$ My inquiry focuses on the fictional space of The Lunar Trilogy as a nexus between the old and new traditions of romance and early modernist imagination, drawing inspiration from the broadly-conceived spatial turn in the humanities. ${ }^{6}$ Specifically, I position my argument within the critical tradition-dating to Harold Bloom's seminal 1969 essay "The Internalization of Quest-Romance," which traces the use of romance narratives (be they historical, scientific, imperial, or other) for examining modern subjectivity and its relations with what Max Weber calls the "disenchanted world."7

\section{The Lunar Trilogy and Its Reception}

The first book of the trilogy, On the Silver Globe: The Manuscript from the Moon (Na srebrnym globie: Rękopis z księżyca) was written between 1901 and 1902 and published in $1903 .^{8}$ It was a surprise to many critics due to Żuławski's

3. All quotations come from the following editions: Jerzy Żuławski, Na srebrnym globie: Rękopis z księżyca (Kraków, 1957); Zwycięzca (Kraków, 1959); and Stara ziemia (Kraków, 1959). All translations are mine. When quoting from Żuławski’s work I will use the abbreviations OSG, TC, and TOE to denote On the Silver Globe, The Conqueror, and The Old Earth, respectively.

4. Northrop Frye, The Secular Scripture: A Study of the Structure of Romance (Cambridge, 1976).

5. Lukács states, "[e]very form is the resolution of a fundamental dissonance of existence; every form restores the absurd to its proper place as the vehicle, the necessary condition of meaning." György Lukács, The Theory of the Novel (Cambridge, Mass, 1971), 62.

6. For a general overview of the spatial turn in the humanities and social sciences, see essays collected in The Spatial Turn: Interdisciplinary Perspectives, ed. Barney Warf and Santa Arias (London, 2009).

7. See Harold Bloom, “The Internalization of Quest-Romance” in Harold Bloom, ed., Romanticism and Consciousness: Essays in Criticism (New York, 1970), 3-24 (originally published in The Yale Review in 1969). Weber's famous definition of the modern world as "disenchanted" appears in Max Weber, "Science as a Vocation" in Hans H. Gerth and C. Wright Mills, eds., From Max Weber: Essays in Sociology (London, 2001), 129-56.

8. For a more detailed publication history of individual books in the trilogy, see Helena Karwacka, "O trylogii fantastycznej Jerzego Żuławskiego" in Zeszyty Naukowe Uniwersytetu Łódzkiego. Nauki humanistyczno-społeczne 25 (1962), 83-84. 
employment of the genre of scientific romance, hitherto virtually absent from Polish literature. The novel tells the story of a hapless expedition to the moon, narrated through the retrieved personal journal of Jan Korecki, one of the expedition's members. He starts writing his journal in the immediate aftermath of a crash landing on the moon that kills the leader and organizer of the expedition, leaving the remaining four participants confused and in short supply of air. The group undertakes a difficult journey to the lunar North Pole, in hopes of finding suitable conditions for settlement. Before they reach their destination, another member of the crew dies, leaving only two men and a woman. On the other side of the moon they indeed find a green paradise. However, a conflict ensues between the two men over the woman Marta, who-in the role of a new Eve-would start a lunar civilization. The trauma resulting from this conflict destroys the lives of Marta and her new "husband" Piotr Varadol, making Korecki a lonely and melancholic guardian and teacher of the new generation. The physical conditions on the moon make Marta's children and their offspring the dwarfish Selenites (named after Selene, the Greek goddess of the moon), who reject Korecki's educational efforts, instead making him into a cult figure referred to as the Old Man. Alienated and melancholic, he finally abandons the growing Selenite tribe and returns to the other side of the moon to send his manuscript (the text of the novel) to the Earth and to end his life.

The other volumes of The Lunar Trilogy-The Conqueror and The Old Earthappeared much later, in 1910 and 1911, respectively. The Conqueror begins with another spaceship landing on the lunar North Pole. Its sole passenger is Marek, a young adventurer who wants to follow in the footsteps of the first expedition. The seven hundred years that have passed since Korecki's death have witnessed the growth of the Selenite tribe into a civilization organized around the cult of the Old Man. In the meantime, this civilization has been conquered and colonized by an ancient race of lunar creatures known as Sherns [szernowie]. Marek is immediately recognized by the Selenites as the reincarnated Old Man who has come to fulfill the messianic promises of several generations of their prophets. Seeing the desperation and degradation of the new humanity, Marek willingly assumes this role and, armed with weapons brought from Earth, leads a rebellion and then a successful campaign that conquers the demonic Sherns. He soon learns, however, that his victory will never alleviate the danger of the old race, which makes many Selenites doubt his divine nature. After retreating from the war, he attempts to use his position to improve the lunar society by introducing social and political reforms. Threatened by the changes, Marek's former supporters in the priestly caste turn the people against him. His crucifixion at the end of the novel marks the birth of a new myth.

Before Marek's downfall begins in The Conqueror, his spaceship is accidentally taken back to Earth with two Selenites onboard. Their misadventures on the future Earth constitute one of the two interlacing plots of The Old Earth. The other one revolves around Jacek, a brilliant inventor who, together with a few other characters, recognizes the catastrophic impasse to which scientific progress has led mankind. The masses have benefitted from it in all kinds of ways, but once their need for comfort and security has been satisfied, they turn away from it. Jacek desperately seeks a way to overcome this situation, but it seems to be too late to awaken humanity's curiosity for metaphysics. Art and thought are disappearing from Earth. In an act of desperation, Jacek 
builds a bomb that could potentially destroy the entire globe. He is courted by different factions, including the leader of the world's new proletarians, to hand over this powerful weapon. In the end, after events have led to an aborted revolution of the working classes, a bourgeois government representing a hedonistic and consumerist society dissolves the scientific council and all other institutions conducting scientific research. History comes to a dystopian end. Jacek disappears, teleported into the unknown by his newfound mentor, the Buddhist mystic Nyanatiloka. ${ }^{9}$ Materet, a Selenite who came to appreciate all of Earth's history and culture, is the only person to mourn the ultimate demise of human civilization.

On the Silver Globe received generally positive reviews and became hugely popular; the other two books were less so, mostly due to the perceived repetitiveness of the fantastic tropes. ${ }^{10}$ Almost all reviewers wrote about Jules Verne's influence on On the Silver Globe, although they also pointed out the psychological realism and poetic qualities that put Żuławski's work above that of the French author. ${ }^{11}$ The only negative review appeared, somewhat surprisingly, in Zenon Przesmycki's Chimera, an artistic-literary journal that was one of the flagship publications of Young Poland. The author of the review, Maria Komornicka, writing under the pseudonym Piotr Włast, described the novel as derivative, indicating that "the lack of technical inventiveness [pomystowości technicznej], adventurous imagination, and poetry have made this journey to the moon a boring and, in the amorous parts, disgusting romance, decorated here and there with pretty depictions of the landscape." She also suggests that the book reminds one of the "table of contents of sociology textbooks.... There are the newest scientific hypotheses, but there is no creative synthesis, no intuition."12 The comments about the lack of an authentic poetic talent must have been particularly upsetting for Żuławski, whose essayistic work repeatedly celebrates creativity and originality as supreme artistic values. What is interesting about this review is that it would become symptomatic of a certain tendency in the critical reception of Żuławski's work, which has also affected scholarly criticism-namely, the tendency to separate Żuławski the intellectual from Żuławski the artist. His dramas and prose are often considered mere allegories of the ideas contained in his essays. ${ }^{13}$ Likewise, the

9. Presumably named for the historical Nyanatiloka (1878-1957), born Anton Gueth, who was the first European to become a fully ordained Buddhist monk. See Bhikkhu Nyanatusita and Hellmuth Hecker, The Life of Nyanatiloka Thera: The Biography of a Western Buddhist Pioneer (Kandy, 2008).

10. Ibid.

11. See Jan Sten, “Nowe powieści,” Krytyka vol. 1 (1903), 376-78; Ignacy Matuszewski, "Na srebrnym globie” (review), Tygodnik Ilustrowany 43 (1903); see also: Helena Karwacka, "O trylogii fantastycznej Jerzego Żuławskiego.”

12. Piotr Włast [Maria Komornicka], "Na srebrnym globie” (review), Chimera 9 (1905), 335.

13. See Jerzy Kreczmar in his introduction to the collection of Żuławski's essays: Jerzy Kreczmar, “Wstęp” in Jerzy Żuławski, ed., Eseje (Warszawa, 1960), 5-14. Indeed, most articles dedicated to the trilogy focus on the author's social and historiosophic ideas, considering his trilogy as yet another platform for expressing his intellectual pursuits. Consider, for example, titles of essays collected in Jerzy Żuławski. Życie i twórczość, ed., Eugenia Łoch (Rzeszów, 1976), such as "Społeczne i filozoficzne poglądy Jerzego 
authorship of The Lunar Trilogy is most often assigned to the former Żuławski ("the intellectual"). With a few notable exceptions voiced in relatively recent criticism of Żuławski's work, particularly by Miklaszewska and Trześniowski, Eugenia Łoch's call for further inquiries into the narrative patterns in this work remains unanswered..$^{14}$ My reading suggests that the unique combination of romantic and modernist elements at work in the trilogy shapes Żuławski's philosophy to the same extent as it is shaped by it.

\section{Popular Romance and Imagined Geographies}

"Any history of the romance will in one sense be a record of decadence," writes Gillian Beer. ${ }^{15}$ Indeed, despite its idealism and wish-fulfilling utopianism, the modern romance seems to be a thoroughly nostalgic mode of fiction, preoccupied with holding on to the sense of wonder and amazement that is inevitably slipping out of the world. The simplest definitions characterize romances as fantastic tales of love and adventure, usually focused on the hero's quest. The latter typically has a happy end, although in some cases the protagonists die while the values they fight for triumph. The fictional universes depicted in romances are strongly polarized: there is light and darkness, with very few shades of grey in between. One the one hand, there is the world that the human consciousness finds desirable: an idealized world based on such eternal values as beauty, love, and wisdom. On the other hand, there is a world of negative projections: "the world of the nightmare and the scapegoat, of bondage and pain and confusion ... of perverted or wasted work, ruins and catacombs, instruments of torture and monuments of folly." ${ }^{16}$ These two forces are in perpetual conflict and find embodiment in the struggle between the hero and the anti-hero (who can be a human or a monster). Romances, unlike realist novels, have a strong "fairy tale" feeling about them, since the two forms share similar plot structures and what Alastair Fowler calls a mood ("an emotional coloration"). ${ }^{17}$ They present us with an idealized version of our world in which social problems and anxieties can find appealing symbolic solutions.

In The Political Unconscious, Fredric Jameson points to the historical circumstances under which romance flourishes and diminishes throughout

Żuławskiego w Trylogii fantastycznej” or "Utopia i historiozofia w poglądach Jerzego Żuławskiego na przykładzie Starej Ziemi.”

14. See Miklaszewska, "Katastrofizm w twórczości Jerzego Żuławskiego"; Dariusz Trześniowski, "Młodopolskie źródła fantasy. Trylogia księżycowa Jerzego Żuławskiego" in Janina Szcześniak, ed., Fantastyka XIX i XX wieku. Granice i pogranicza (Lublin, 2007), 51-60; Dariusz Trześniowski, W stronę człowieka. Biblia w literaturze polskiej (1863-1918) (Lublin, 2005), as well as Eugenia Łoch, “Techniki narracyjne Trylogii księżycowej Jerzego Żuławskiego” in Jerzy Żuławski. Życie i twórczość, 181-95.

15. Gillian Beer, The Romance (London, 1970), 1.

16. Northrop Frye, Anatomy of Criticism: Four Essays, ed. Robert D. Denham (Toronto, 2006), 136. Frye's theories of romance laid out in Anatomy of Criticism: The Secular Scripture: A Study of the Structure of Romance (Cambridge, Mass., 1987), and, to a lesser extent, Notebooks on Romance, Michael Dolzani, ed., (Toronto, 2004) are the cornerstone for modern scholarship on the genre.

17. Alastair Fowler, Kinds of Literature: An Introduction to the Theory of Genres and Modes (Cambridge, Mass., 1982), 67. 
the nineteenth century in response to what he calls the development of late capitalism. The persistent role of this mode, he argues, is to replenish a sense of wonder in a disenchanted world of accelerating rationalization and modernization. In order to do so, it needs to draw on "the raw materials of magic and Otherness"-the still unexplored or little-known areas and populationsusing them as a kind of scaffolding for its adventurous plots. ${ }^{18}$ Needless to say, such magical zones-once abundant in the premodern world-are rapidly diminishing with the onset of modernity and its cartographic conquests.

Thus, for both Beer and Jameson, romance is an ever-decaying and vanishing phenomenon, both as a mode of fiction and as a type of sensibility. John A. McClure offers an even more historically-specific version of the above narrative by viewing Jameson's theory in geopolitical terms in the context of late imperial culture. He observes that the period between 1870 and 1914 witnessed an unprecedented tightening of the global network of communications, international trade, and colonial relations. Various sites of "adventure and Otherness, "magic and providential mystery," which in the literary imagination take the form of lost lands, dark continents, utopias, earthly paradises, and frontiers, could no longer be accommodated geographically. ${ }^{19}$ The colonial project came to completion. "At this moment," writes McClure, "when it became impossible to ignore the prospect of global modernization, the eradication of the last elsewhere, the writers of imperial romance began to become uneasy."20 Thus, works such as those of Joseph Conrad, which the critic calls late imperial romance, began to project this uneasiness by making into a quest the very act of regaining the sense of enchantment, adventure, and discovery. ${ }^{21}$

Because of the scope of his research, which is limited to Anglophone literature, McClure does not include the work of Verne in his discussion. However, the French author plays a pivotal role in the process described above. Verne's Voyages extraordinaires, an impressive body of fifty-four novels, present a world where, despite the complete quantification of time and space, utopian dreams of temporary escape from bourgeois boredom can be projected onto the new means of locomotion. Darko Suvin calls this body of work "an epic of communication for the age of industrial liberalism."22 Verne's rendition of the relationship between the scientific progress and space is a Newtonian one in at least two ways. First, the fantastic spaces described in his novels do not affect in any radical way the status quo of European civilization. Second, as technology and communication gradually deplete the world of the old sites for romance, they manage to produce new ones, although only temporarilythese new sites are no more than spatial extensions for various new modes of locomotion and, as mentioned, exist only for the duration of a given journey. With Verne's fantastical vehicles, the sky, earth, oceanic depths, and cosmic

18. Fredric Jameson, The Political Unconscious: Narrative as a Socially Symbolic Act (London, 2002), 117.

19. John A. McClure, Late Imperial Romance (London, 1994), 9.

20. Ibid., 11.

21. For more on Conrad's use of romance, see Katherine Isobel Baxter, Joseph Conrad and the Swan Song of Romance (Burlington, 2010).

22. Darko Suvin, Metamorphoses of Science Fiction: On the Poetics and History of a Literary Genre (New Haven, 1979), 150. 
vacuum become spaces of infinite possibilities for adventurous romance that can be "activated" whenever desired, spaces which do not interfere with the rationalizing processes of the modern world.

Those who continued Verne's legacy, however, could no longer share his optimism. Even Verne's own work displayed increasingly darker overtones towards the end of the nineteenth century. H.G. Wells, who continued and further developed the form of scientific romance, presents the wondrous element as a disrupting force that undermines the civilized world. If Verne's work shares many traits with imperial romance, the author of The Time Machine leans more towards the tradition of Gothic romance. ${ }^{23}$ In his work, "the vast, menacing, stupid powers of nature as they appear to a technologically undeveloped society" once again come to haunt the civilized metropolis. ${ }^{24}$ Wells' world, unlike that of Verne, is no longer a rational universe filled with exciting possibilities for adventurous exploits, but a world surrounded by darkness, filled with anxieties about what may lurk in the not-too-distant future. Reason and morality, in terms of which late-nineteenth-century European society wants to see itself, turn out to be made of a very thin fabric. When one of his protagonists returns to England after experiencing the horrors of Dr. Moreau's experimental island, he observes the faces of his countrymen and feels "as though the animal was surging up through them; that presently the degradation of the Islanders will be played over again on a larger scale." 25

The comparative view of the work of Verne and Wells shows that differences in their styles closely correspond to the transition that Jameson and McClure (and to an extent also Frye) describe in their studies. On the one hand, there is a sense of moving away from the existing sites of romance to virtual ones, which now have to be created artificially by the new science. On the other hand, one can talk of the "return of the repressed," as the hitherto externalized spaces of otherness begin to manifest themselves at home and threaten the very fabric of the familiar world of the everyday. Technological achievements of reason and progress can no longer serve as magic weapons and amulets that aid humans in their fight with forces of nature and unreason, because this conflict now takes place mainly in the inner world of the human psyche.

These two trajectories of generic development form the system of coordinates for Żuławski's literary universe. The romantic conceptualization of space outlined above, even though a product of a particular historical and cultural context, is not limited to it, but becomes a part of the grammar of the genre. As Jameson writes: "the ideology of the form itself . . . persists into the later, more complex structure as a generic message which coexists-either as a contradiction or, on the other hand, as a mediatory or harmonizing mechanism-with elements from later stages." ${ }^{26}$ Thus, by referring to the genre of scientific romance, Żuławski becomes a participant in its tradition, and his

23. For an excellent discussion of Wells' early romances in the context of the British romance revival, see Linda Dryden, The Modern Gothic and Literary Doubles: Stevenson, Wilde, and Wells (New York, 2003).

24. Frye, Anatomy of Criticism, 136.

25. H.G. Wells, The Island of Dr. Moreau (New York, 2002), 183.

26. Jameson, The Political Unconscious, 128. 
work inherits all the problems with which this tradition engaged in the process of its formation.

\section{Imagining Space in the Post-Romantic Age}

By situating his work at the intersection of the nascent science fiction genre and modern romance in general, Żuławski consciously positions it in the context of a broadly-conceived west European culture. However, his situation as a Polish author writing from Galicia at the turn of the century cannot be overlooked. As Larry Wolff argues, from the late eighteenth century, when it became a part of the Enlightenment Habsburg project of "civilizing the East," until its dissolution with the collapse of the Habsburg Empire after 1918, the province of Galicia had been as much a geopolitical idea-a political and cultural invention-as a real place. ${ }^{27}$ The ephemeral status of this land, as a virtual site for various enlightened and national (Austrian, Polish, Ruthenian, Jewish) projects, could easily have imprinted itself on Żuławski’s construction of the lunar landscape, which likewise is in equal parts an accurate representation of known facts about lunar geography and fantastical invention based on long-discredited theories (such as the idea of an inhabitable "other" side of the moon). The problematic relationship between metropolitan Vienna and "peripheral" Galicia may have also provided the author with a more direct experience of what we may call cultural colonialism than the scientific romances of Verne and Wells; it is no coincidence that each book of the trilogy is modeled on a distinct colonial narrative: from the discovery and population of a new world in On the Silver Globe to a heroic conquest led by a discoverer from Earth (whom locals take for a deity in The Conqueror) and, finally, two "primitives" arriving in the "metropolis" that is Earth in The Old Earth. One might even suspect a compensatory impulse at work in the trilogy, where Poles-as representatives of western civilization-are put in the role of colonizers, which strikingly contrasts with the actual status quo of Poles subjected by the partitioning powers to various forms of cultural warfare.

Żuławski, despite his engagement with the international culture of modernism, was strongly influenced by the Polish Romantic tradition, which called on the one hand for active resistance against the partitioning powers-particularly Russia-and on the other hand for preserving Polish national symbols and cultural heritage. Żuławski's father had been an insurgent in the 1863 January Uprising, and Jerzy himself died in World War I as a soldier of the Polish Legions. The intellectual influence is reflected in his many patriotic poems and a close engagement with Polish Romantic literature. In many respects, The Lunar Trilogy is much closer to such Romantic works as Juliusz Słowacki’s Anhelli (written 1848) or Zygmunt Krasiński’s Un-divine Comedy (Nie-Boska komedia, 1835) than it is to the more contemporary Polish science fiction of a positivist bent, such as the works of Władysław Umiński. ${ }^{28}$ Although the presence of Poland and the

27. See Larry Wolff, The Idea of Galicia: History and Fantasy in Habsburg Political Culture (Stanford, 2010).

28. For more information on Władysław Umiński and traces of science-fictional imagination in Polish positivist literature, see Antoni Smuszkiewicz, Zaczarowana gra: Zarys 
Polish national cause is not conspicuous in the trilogy, it cannot be overlooked. After all, one of key members of a historic, international expedition to the moon is a Pole (Korecki), which, given his role of a cultural midwife, makes Polish the founding language of the Selenite civilization. In The Conqueror, the Selenites' successful resistance against their oppressors-whose seat of colonial power is modelled after the Warsaw Citadel, the symbol of Russian tyranny for Poles-is the unrealized dream scenario of Polish nineteenth-century insurgencies. In The Old Earth, the future Warsaw is presented as a global metropolis rather than a peripheral, colonial city to which Russian imperialism reduced it over the course of the nineteenth century.

In attempting to make the science fiction genre a medium for reflecting on the past and future course of human civilization (and Poland's pivotal role in it), Żuławski's work also has an important antecedent in Adam Mickiewicz's utopian A History of the Future (Historia przyszłości), the visionary aspect of which was in many respects more daring and thought-provoking than that of Verne's works. Alas, A History of the Future was never completed and survives in Polish literary tradition only in the form of scattered fragments (from seven different drafts) and secondhand written accounts by Mickiewicz's friends and editors. ${ }^{29}$ Nonetheless, as Antoni Smuszkiewicz notes, even as a trace of an unrealized idea it played an important role in the development of the Polish fantastic imagination. One may find echoes of this "ghostly" epic in Żuławski's playful use of the found-manuscript device in On the Silver Globe, the three versions of the ending of the Conqueror, and the history of the "future" read by Jacek at the beginning of The Old Earth. Even if these parallels are purely accidental, however, Mickiewicz's criticism of scientific progress and technical imagination deprived of any form of spiritual striving, to which he also gave expression in his poetry (to name but the famous "Romantyczność") and lectures at the Collège de France in the 1840s, could not have been overlooked by such an avid student of Polish Romanticism as the author of The Lunar Trilogy. ${ }^{30}$

Żuławski's goals are clearly universal in scope, as dictated by his earlymodernist preoccupation with the fate of culture as a universally-shared system of values and spiritual heritage of mankind. Yet he also clearly saw Polish culture-in the Romantic vein-as an integral part of western civilization and, by extension, human civilization as a whole.

\section{Romancing the Moon: Life and Death on the Silver Globe}

On the Silver Moon, more than the two other novels in the trilogy, brings this spatial duality of late-nineteenth-century romance to the fore. From the very beginning of the novel, the moon is presented as a romanticized space. The author

dziejów polskiej fantastyki naukowej (Poznań, 1982), 60-100.

29. Ibid., 34-52. See also Stefania Skwarczyńska, Mickiewicza "Historia przyszłości” i jej realizacje literackie (Łódź, 1964).

30. For more information on Mickiewicz's critique of nineteenth-century rational and utilitarian attitudes towards technological and scientific progress, as well as his ideas about the need for "spiritualizing science," see Monika Stankiewicz-Kopeć, "Refleksje cywilizacyjne poetów pierwszej połowy XIX wieku-'Prelekcje paryskie' Adama Mickiewicza,” Episteme. Czasopismo naukowo-kulturalne 16 (2012), 191-202. 
of the introduction asserts that it is "not a hospitable world" and that what was known about the side of the moon visible from the Earth "was enough to discredit this globe completely in the opinion of people dreaming about settling worlds other than the Earth." ${ }^{31}$ This last assertion turns out to be false, as there are some would-be explorers who persist in fantasizing about the unknown: "Who knows - they thought from time to time, elevated by the grandeur of their enterprise-maybe they will find on that other, mysterious side of the moon a magical and strange paradise [raj czarodziejski i dziwny], a new world, quite different from the earthly one, but hospitable?" 32 One recognizes here the familiar motif of a prohibited land, a dark continent, and the lost land/paradise/holy grail/treasure hidden in the midst of it-a motif used with great success in classical colonial romances, such as those by Rider Haggard or Rudyard Kipling. The moon thus functions as an exotic site for romance, even though its geography is outlined in the novel in accordance with the state of knowledge about this natural satellite circa 1900 and, at least in the first part of the novel, attempts to give the journey across the visible part of the moon some plausibility.

The calm and informative style of the introduction, whose genre is that of a newspaper story, quickly gives way to the highly impressionistic tone of Korecki's manuscript. In the explorer's first-person account, the moon becomes a magical space where cultural fears and hopes can be projected into figures of horror and wonder, respectively. The lunar landscape that spreads itself before the explorers is a cosmic wasteland. It alternates between vast and desolate open spaces (like the monotonous and depressing Mare Imbrium) and the sublime chains of mountains (the crater of Eratosthenes). The silver light reflected from the Earth partially illuminates "the bottomless black sky," making white and black the only perceptible colors. ${ }^{33}$ It is consistent with the demonic imagery of Frye's theory of archetypal meaning as the world that human desire rejects, the world of bondage and pain and "monuments of folly." 34 The visible side of the moon is in part all of those things, as will soon become evident. It is first and foremost an image of hell. Korecki's evocation of Dante demonstrates that clearly enough:

Unconsciously I heard in my head the words of Dante:

Vero è che in su la proda mi trovai

Della valle d'abisso dolorosa ...

[In truth I found myself upon the brink of an abyss . . . ]

And in recollection of those words, in my mind ... awoke the vision of Dante's hell, which truly could not be more terrifying than what I had before my eyes! The smoke pyres moving on the bottom of the giant hole seemed to me groups of condemned ghosts, spinning around the monstrous figure of Lucifer, whose shapes were assumed by the nearest of the volcanic peaks. ${ }^{35}$

31. $O S G, 16-17$.

32. Ibid., 18.

33. Ibid., 28.

34. Frye, Anatomy of Criticism, 136.

35. OSG, 60 . 
Like the Italian poet, the members of the expedition have to traverse hell before they access a purgatory of sorts (the North Pole of the moon) and paradise (the other side). Unlike in Dante, however, the lunar rocky desert is a hell of ossified and frozen forms rather than fiery passions; marked by sterility rather than excess.

Mapped by generations of astronomers, its geographic landmarks carrying Latin names linking it with the history of western civilization (maria, Eratosthenes), dead city-like formations, and ghostly apparitions, the moon appears to be yet another example of the vanishing "magical spaces" discussed by Jameson and McClure, all the more tragic because it had been conquered by the instruments of science even before it could become an object for exploration. The pursuit of transgression-of a mythical space that could rejuvenate man's metaphysical link with the cosmos-thus results in a bitter disappointment, as the lunar landscape turns out to be a mirrored reflection of the Earth itself, a geographic embodiment of the Earth's spiritual condition, impoverished by materialism and scientific rationality. When shining above the silver globe, the Earth literally stares down upon humans like an evil omen: "we saw her above us. She was almost full. She looked like an eye, wide open in amazement; now the eyelid of shadow slowly falls on this terrible, still eyeball." 36 The feminine and the supernatural become one as the eye is identified with a vengeful, maternal deity: "[the] open eye, merciless and watchful, [that] stares intently and with amazement at [those] who escaped from her with [their] bodies-first of all her children." 37

This gaze constantly haunts the explorers, reminding them about their transgression and the punishment that awaits them. When the Earth becomes eclipsed, its shadow veils everything in a shroud of darkness, while the planet becomes a dark icon in the sky: "the black spot of the Earth now looked like the emanating hole of some monstrous well, drilled in the starry sky." 38 The sterility and stillness of the lunar landscape evoke the fairy-tale image of a cursed or enchanted land. At the same time, however, it is a striking example of the misogynist fantasies of early modernism refracted through the prism of the landscape. The cold, distant, and cruel Earth is the embodiment of the archetypal femme fatale whose figures dominate literature and the fine arts associated with early modernism (such as Lilith, Judith, Salome, and the Sphinx). ${ }^{39}$ Zuławski's moon is thus a heterogeneous space in which all kinds of symbolic representations of the demonic world-popular as well as highcultural-can coexist.

Such a vision of the world-dead, cold, and sterile-is the antithesis of the colonial and metaphysical fantasies of the members of the expedition, who expect to find a lost paradise on the moon. For them, the search for what is on the other side of the "silver globe" is not simply a yearning for a place-a kind of natural utopia-but first and foremost a spiritual quest for the Holy Grail

36. Ibid., 27.

37. Ibid.

38. Ibid., 95.

39. For more examples of the femme fatale archetypes in the art and discourse of early modernism, see Bram Dijkstra, Idols of Perversity: Fantasies of Feminine Evil in Fin-desiècle Culture (Oxford, 1986). 
and all it stands for, especially the dream of immortality. Yet every quest for an eternal life in literature begins with what Northrop Frye calls a narrative of "descent": the journey through the land of the dead..$^{40}$ As I have already indicated, mortality, associated with the primal sin, closely connects the visible side of the moon with the abandoned home world. As Korecki reflects, "[they] had escaped from the Earth, but death, the great mistress of earthly tribes, traversed with [them] those spaces and now reminded [them] right away that she was with [them]-cruel and victorious as always." ${ }^{\text {411 }}$ But it is not death itself that is their curse, as Korecki would like to believe, but a kind of immortality that instead of embodying dreams of vitality, youth, and eternal rejuvenation of life brings with it the burden of melancholic timelessness. As such, this form of immortality is close to post-Lacanian readings of Freud's concept of the death drive (Todestrieb) as the ineradicable excess over libidinal desire that persists even beyond the life-sustaining regulations of the pleasure principle. ${ }^{42}$ Slavoj Žižek writes:

the Freudian death drive has nothing whatsoever to do with the craving for self-annihilation, for the return to the inorganic absence of any life-tension; it is, on the contrary, the very opposite of dying-a name for the "undead" eternal life itself, for the horrible fate of being caught in the endless repetitive cycle of wandering around in guilt and pain. The paradox of the Freudian "death drive" is therefore that it is Freud's name for its very opposite, for the way immortality appears within psychoanalysis, for an uncanny excess of life, of an "undead" urge which persists beyond the (biological) cycle of life and death, of generation and corruption. ${ }^{43}$

According to the author of The Parallax View, the most common metaphorical representation of the death drive is the figure of the undead. And indeed, it is not death but deathlessness that truly terrifies Żuławski's characters. The eye of the Earth is a "glass specter [upiór]" that radiates "ghostly light [upiorne światto]." "44 Korecki's imagination transforms the scenery before his eyes into "a theater of giants, terrible, skeleton giants [kościotrupie olbrzymy]." "I wouldn't be surprised," he says, "if those mountainsides filled with a crowd of those giant skeletons, moving slowly in the light of Earth and taking spectators' seats. ... It seems to me that I see all of that." ${ }^{55}$ O'Tamor's body, like those of the prophets that centuries later will await the return of the Old Man, does not decompose in the thin atmosphere of the moon. The Old Man himself is the recipient of this strange gift of unwanted immortality. In their journey towards the North Pole, the explorers discover what seems to be ("under the

40. Frye, Secular Scripture, 97.

41. OSG 31.

42. For the original formulation of the idea as an instinct striving towards the erasure of all psychic tensions via a return to the inorganic state (i.e. death), see Sigmund Freud, "Beyond the Pleasure Principle," in Beyond the Pleasure Principle, Group Psychology, and Other Works (1920-1922) in James Strachey, ed., The Standard Edition of the Complete Psychological Works of Sigmund Freud vol. 18 (London, 1955).

43. Slavoj Žižek, The Parallax View (Cambridge, Mass., 2006), 62.

44. OSG, 27, 25.

45. Ibid., 78. 
Earth's light”) the ruins of a decrepit, long-dead city. ${ }^{46}$ The encounter with this eerie site results in the untimely death of another expedition member who ventures to investigate it. Before he passes away a few days later, he recalls encountering there the apparitions of three dead astronauts, including O'Tamor, the leader of the expedition:

I couldn't move, turn away. ... Then they started speaking, yes, speaking, and I heard their voices even though there was no air... . They told me how I'll die and how you'll die, the two of you. They marked the day and the hour. They also said that one does not leave Earth without being punished and that one does not look with impunity into mysteries hidden from human eyes. ${ }^{47}$

The flight from Earth is once more equated with mystical transgression and a venture into the realm between life and death. "There are strange riddles and mysteries," reflects Korecki: "To this petrified globe there have already come people and Death; maybe together with people and their constant companion, Death, there also came that Thing unknown, which on Earth for centuries has been escaping all knowledge, all research and inquiries?" 48 In Freudian terms, it is "the return of the repressed" that characterizes the late-nineteenthand early-twentieth-century romance, from the Gothic revival to H.G. Wells' early cycle of romances; magic and otherness, eradicated from the map by the tightening of global networks of exploration and trade, which manifest themselves at home as evil and menacing (often supernatural) forces. "That Thing unknown" therefore stands for the lost metaphysical imagination, rejected by secularist rationalism and now returned as a haunting presence.

The Old Earth shows the final stage of this process, a globe where all of Verne's dreams of infinite travel can finally be realized, but unlike in the early romans scientifiques, they fail to generate new possibilities for excitement, romance, and adventure. The utopia of scientific progress turns out to be a parody of itself, a dystopian world where everything is possible, but no one has the desire to reach out to those possibilities. As one of the protagonists reflects on this problem:

After the period of unheard-of, extraordinary inventions, when one discovery gave birth to ten new ones and it truly seemed that humanity was on the path of some fairy-tale progress without an end ... there came a complete halt, as if the mysterious forces of nature, which were supposed to serve man, had exhausted their combinations and, all harnessed to the triumphant chariot of human well-being, had nothing more to reveal. ${ }^{49}$

His account is further amplified by the disappointed confession given by Jacek's teacher, Lord Tedwen, in which he states the impossibility of ever realizing a utopia. ${ }^{50}$ Speaking in front of the scientific council of the United States of Europe, the great scientist thus concludes this moment of human history: "we circle in an errant movement, like fish inside a glass bowl that cannot be

46. Ibid., 113.

47. Ibid., 146.

48. Ibid., 147.

49. TOE, 17 .

50. Ibid., 136. 
shattered. The sun is far behind us, coldness embraces us." ${ }^{11}$ Significantly, he addresses the problem of mankind's intellectual stagnation by evoking the theory of entropy and the heat death of the universe ("thermal degeneration") originating in the ideas of William Thomson (Lord Kelvin, the nineteenthcentury scientist and mathematician who served as the model for Żuławski's Lord Tedwen). ${ }^{52}$ Grabiec, a cynical proletarian revolutionary, describes this reality in more primeval terms: "today's world is like a monstrous animal with a massive belly that expanded at the expense of the body's legs and head." 53

What Frye calls "demonic imagery" manifests itself on almost every level of composition in the last novel of the trilogy: it is reflected in the resignation and despair felt by characters such as Jacek or Lord Tedwen; the petty selfinterest and violence of Grabiec and the proletariat; the blind hedonism of the middle classes, which value comfort over anything else; and finally, the fierce destructive passion of Aza, the novel's femme fatale and artist figure. As in On the Silver Globe, this spiritual state also finds its mirror in the inorganic world of the desert surrounding the city of Aswan, where most of the action takes place, and in images such as the ruined temple of Egyptian deities turned into a "bazaar booth" [buda jarmarczna] of a concert hall. ${ }^{54}$ Jacek's deadly invention, the bomb that can spread massive destruction through a communications network across the globe, adds another level to this metaphor by rendering all of the Earth virtually but not yet effectively dead, which is yet another form of the state of deathlessness that terrifies Korecki on the moon. Unsurprisingly, the only way out is offered by Nyanatiloka, who represents Eastern mysticism and hence spirituality, irrationality, and the transcendental.

Opposed to this demonic imagery of the dystopian Earth and the barren side of the moon are various spatial manifestations of the lost "sense of wonder," most notably the paradisiacal hidden side of the moon. The search for such a magical space is what drives members of the first expedition to abandon the Earth and come to the ethereal lunar world in On the Silver Globe: "when I was a child, it was too cramped for me on Earth," admits Korecki towards the end of his manuscript, "and I constantly flew with my winged thoughts to those distant worlds, shining in the firmament." behind Marek's journey, struggle, and demise in The Conqueror. Finally, in The Old Earth, where such places do not exist, every page is an account of "a determinate, marked absence at the heart of the secular world." 56

As Korecki and his companions make their way to the other side of the moon, their vehicle becomes the new Ark: the presence of dogs (a mother and

51. Ibid., 216.

52. See Mason Tattersall, "Thermal Degeneration: Thermodynamics and the HeatDeath of the Universe in Victorian Science, Philosophy, and Culture," in Decadence, Degeneration, and the End: Studies in the European Fin de Siècle, ed. Marja Härmänmaa et al. (New York, 2014), 17-34; for more information on the significance of the heat-death theory and other forms of catastrophism for Żuławski’s imagination, see Miklaszewska, "Katastrofizm w twórczości Jerzego Żuławskiego."

53. TOE, 188.

54. Ibid., 55.

55. $O S G, 382$.

56. Jameson, The Political Unconscious, 121. 
two puppies) and a deluge that carries it away later in the novel are obvious enough references. It is a microcosm that, thanks to Marta's efforts, acquires the aura of a domestic space, "the form imposed by human work and desire" on the natural world, to recall Frye's definition of the archetypal paradise. ${ }^{57}$ She is the first one to evoke a nostalgic and sympathetic image of the Earth during the journey, and it is her description of it that later becomes the fabric of other characters' dreams. She soothes Tomasz, her dying lover: "On Earth the air is blue, and clouds walk upon it. There is a lot of water on Earth, whole seas of it. On the shore there are sand and colorful seashells. There are plains, where such aromatic, sweet, moist flowers grow ... Behind the plains are forests, full of different animals and singing birds." Korecki and Varadol listen to her words as if it were "the most beautiful, magical fairy tale." ${ }^{\text {8 }}$ This vision of Earth, which recurs as a dream motif throughout On the Silver Globe, gradually materializes for the protagonists as the silent and eerie paradise on the other side of the moon: "Now we breathe freely under a sky as blue as that on Earth, on the seaside of a real, wavy sea, and we look at forests of strange and incredible plants." ${ }^{59}$ But there is more to this scenery than a realized ideal of virginal wilderness.

The lunar "lost world" is first and foremost a magical space uninhibited by the spectral presence of the Earth, a space where all the nightmarish dreams, hallucinations, and visions mentioned earlier give way to a wishfulfillment fantasy. While still on the lunar desert, Korecki writes: "It still seems to me that I'm dreaming or I'm in an opera house at some strange and fantastic spectacle [dziwnej feerii]." ${ }^{60}$ The motifs of sleep, dream, and fantasy recur throughout the entire novel and culminate when Korecki loses consciousness before his companions reach the North Pole and he reawakens in what appears to him a green paradise. When traversing this realm in the first few days, he can only observe that "our whole journey through this valley was like an enchanted dream, full of unexpected and marvelous scenes." 61 Unfortunately for Korecki, however, he will not be able to take part in the new cycle of life and death, which begins with the first Selenites. Even though displaced physically and spiritually, he still belongs to the material world of the Earth, and, like the original leader of the expedition O'Tamor and the Biblical Moses, he cannot enter the new chapter of human history.

Żuławski's return to less subjective modes of narration in The Conqueror does not uproot the magic of this strange world but rather further displaces it in the direction of pre-novelistic forms of the romance. Although the other side of the moon no longer possesses the enchanted aura of a dream world in the second and third books of On the Silver Globe, it is still a highly romanticized landscape, much like those depicted in Romantic ballads, where the supernatural element-or a suggestion thereof-manifests itself through nature and its uncanny bond with the heroes. The marvelous character of this world owes

57. Frye, Anatomy of Criticism, 130.

58. OSG, 147.

59. Ibid., 173.

60. Ibid., 26.

61. Ibid., 204. 
much to Marek's perspective, with which the reader is to identify: "he walked along the bank of the river, over strange flowers and herbs shooting up to life from underneath his feet after a night's rest. . . . He smiled at the 'dwarfs' running alongside him and enjoyed with them the rising sun of the "new day.", 62 Marek's cheerfulness, energy, and youthful optimism find their reflection in the new day of lunar spring. Throughout the narrative, his victories are likewise reflected in images of the sun, green plains, and a peaceful sea, whereas his struggles and defeats are underscored by furious sea storms and volcanic eruptions.

The horizontal division of space in On the Silver Globe and also, to an extent, in The Old Earth, one based on the Earth-Moon relation, is organized in The Conqueror into a much simpler vertical structure. At the top there is the North Pole, the only place where members of the first expedition found moments of happiness (the topos of Paradise before the fall). It is a sacred place where dead saints and prophets rest in their undecaying bodies, awaiting the coming of the savior-the equivalent of King Solomon's Temple. Below are the lands occupied by the Selenites, the world of changing seasons, where the spring of lunar day that announces Marek's arrival is preceded and followed by the wintry lunar night that marks the absence of the solar hero. It is a world of ordinary experience, a fallen world where dreams of paradise are overshadowed by the proximity of hell; here, this shadow has the concrete shape of the dark citadel of Awij, the evil Shern steward. Below this world of men there is the great ocean, which separates the realm of the living (Selenites) from the underworld (Sherns) like the river Styx in Greek mythology. This transitional symbolism of the Ocean is also stressed by the presence of Cemetery Island, where the parents of the Selenite tribe are buried and where Malahuda, the last archpriest of the old faith, retreats after Marek's arrival. At the very bottom is the desolate and sterile domain of the decadent alien race, a land resembling the lunar scenery of the first part of On the Silver Globe. The Shern fortress, towering amidst treacherous mountain chains and holding in its corridors dark and inaccessible secrets, is situated at the very heart of the South Pole, directly opposite the sacred space of the North Pole.

Unlike the first two parts of the trilogy, The Old Earth presents an unambiguously catastrophic (and even dystopian) vision of the future Earth in which human civilization has reached an epistemological "glass ceiling" and atrophies due to the lack of possibilities for further development. Rationalism and instrumental reason thus reveal themselves as poor substitutes for metaphysical imagination. Yet even in this futuristic embodiment of Frye's "demonic world," we find traces of the romantic-utopian imagination, although this time it is relegated to the internalized space of the protagonists' psyches. Thus, the modern imagination-externalized in the demonic and paradisiacal landscapes of the moon in the previous two installments-once again has to face its demons and its hopes on "native soil," as it were: in the human mind. In the last novel of the cycle, idealism and belief in the transformative powers of the imagination reside only in individuals, such as Jacek, Nyanatiloka, and

62. TC, 52. 
Mataret, and so the conflict is no longer manifested in external terms, but rather in the dichotomy between the internal and external spaces.

The spatial architecture of this fictional universe is thus highly polarized: in terms of the dialectic between the utopian/paradisiacal and catastrophic/ sterile visions of the world, but also in terms of the classical dualism between internal (subjective) and external (objective) representations of reality. The dual space in The Lunar Trilogy exists partially as an objective and autonomous entity and partially as an extension of the characters' psyches. The journey to the moon undertaken in On the Silver Globe is both a physical dislocation and a spiritual transgression. Likewise, Marek's historical quest in The Conqueror is a fantasy of his adventure-seeking desire (undercut in the end by the "reality principle"), and the dystopian world of The Old Earth reflects Jacek's growing disillusionment with human civilization.

Żuławski goes a step further than both Verne and Wells in transforming the imaginary geography of his science-fictional setting into a cognitive map of his protagonists' cultural sensibility. Stretched between melancholia after an evanescing sense of wonder and a hope for the possibility of resetting of human history without erasing cultural memory, Żuławski's adventurers quest after the "grail" of re-enchantment. Their pursuit takes them across landscapes that keep reminding them-like the spectral sphere of the Earth haunting Korecki's expedition-that even when we manage to escape to other worlds and to the future, we will always find that our history got there before us. It is in this particular aspect of the setting that the tropes of romance intersect with tropes of the early-modernist discourse: anxiety, metaphysical restlessness, catastrophic imagination, spiritual yearning, fear of the natural world, liminal states of human psyche, and entanglement in the complex web of cultural history (the latter evident in the rich pattern of subtexts and inter-texts). Moreover, we might observe that the relationship between the two modes takes the form of symbiosis. Modernist style and content intensify (and intellectualize) the otherworldliness of Żuławski's landscapes, whereas the dual nature of the romantic geographies creates a stark and dynamic environment in which the various ideological contrasts that pervade modernist discourse can be dramatized and translated into an engaging narrative.

\section{Conclusion: The Lunar Trilogy and the Early Modernist Uses of Romance}

Examining the construction of narrative space in The Lunar Trilogy from the dual perspective of romance and early modernism suggests that the two modes behave similarly to the physical phenomenon of interference, in which one wave superimposes itself on another to create a single wave that is either higher (constructive interference) or lower (destructive interference) in amplitude than those of the two individual waves. In case of the unique novelistic form represented by The Lunar Trilogy, the lyrical and melancholy aesthetics of early modernism resonate with the fantastic aura of romance, and together they strive for an imaginary recreation of the individual's agency vis-à-vis the world by means of unplugging him or her from the network of impersonal forces-whether historical, social, or economic-that diminish that agency. 
The romance organizes the modernist worldview into a polarized semantic space filled with narrative possibilities, although it loses some of the symbolic subtlety and enigma that characterize modernist poetry.

With such an unsteady combination, The Lunar Trilogy continues and at the same time problematizes western popular narratives of scientific and geographical expansion, such as those by Verne, Wells, and their numerous imitators. Żuławski reinterprets these texts in accordance with the early modernist ideology, fixated on modes of transcending and re-enchanting everyday reality. His role can thus be compared to that of his compatriot, Joseph Conrad, whose imperial novels announce the shift "from the heroic political romances of imperialism, which are discredited, to heroic spiritual romances which enact the rediscovery of mystery and depict the disillusioned individual's strong resignation from the world of political engagement," to quote McClure. ${ }^{63}$ Unlike in Conrad, however, the protagonists of On the Silver Globe, The Conqueror, and The Old Earth cannot truly escape either history or politics, which is what distinguishes him from his predecessors in the science fiction genre.

The success of this aesthetic experiment in Żuławski's case is a problematic one. As I already mentioned, with the exception of Maria Komornicka's negative review, the reception of On the Silver Globe was generally positive. Critics appreciated the poetic beauty of the lunar landscapes depicted by the author, the psychological realism of the work, and its philosophical approach to the form of fantastic travel (in the style of Jules Verne). The book went through three editions in Żuławski's lifetime and several more after his death, including the most recent adaptation into an audiobook. ${ }^{64}$ Together with the other two volumes, it has been translated into several languagesRussian, German, Czech, Ukrainian, and Hungarian-in some cases also going through several editions, a fact that testifies to its popularity in central and eastern Europe, at least in the first half of the twentieth century. Although the other two volumes were not as successful in terms of popularity or critical appreciation, they nonetheless managed to integrate with their predecessor and form the unity known as The Lunar Trilogy. In 1976, Andrzej Żuławski, Jerzy's grandnephew, attempted to bring the trilogy to screen on an epic scale as a highly theatrical and artistically-complex allegory of the Polish nation's long struggle for political freedom. Due to the unfortunate intervention of the communist authorities, however, the filming was interrupted and the majority of the materials used for the production were destroyed. The recovered footage was edited and supplemented with a few scenes shot in the 1980s, together with a voiceover describing to the audience the content of the missing scenes. In this crippled form, the film saw the light of day a decade later when, sadly, it could not have the same impact as in the late 1970s.

Hence we may speak of the moderate success of these books as far as readership, criticism, and cultural potential are concerned. Żuławski’s experiment, however, did not find any continuators during his time, not only among

63. McClure, Late Imperial Romance, 12. CD MP3).

64. Jerzy Żuławski, Na srebrnym globie, read by Roman Gancarczyk (Audea, 2010, 
the modernists but also among popular authors. Other early modernist excursions into the fantastic-for example, in Tadeusz Miciński's Nietota: The Secret Book of the Tatra Mountains (Nietota, Ksiegga Tajemna Tatr, 1910) and Priest Faust (Xiadz Faust, 1913) - did not follow the trajectory of the trilogy, focusing more on the supernatural rather than speculative and scientific elements (and that too in a clear separation from the poetics of romance and popular fiction). With the possible exception of Mieczysław Smolarski's The City of Light (Miasto świattości, 1924) and Antoni Lange's Miranda (1924), Polish literature of the 1920s and 30s also could not aspire to the imaginative and philosophical scope of the trilogy and rarely sought to revisit its artistic territory. Żuławski found his most worthy successor only in the second half of the century in Stanisław Lem, whose grand opus of several novels, novellas, and countless short stories became Polish literature's lasting input into global science fiction. Lem openly admitted to being inspired by Żuławski's take on the genre, and his own works, suffused with philosophical themes, archetypal imagination, and stylistic experimentation, can truly be said to have engaged with the form of writing Żuławski introduced into Polish literature. ${ }^{65}$ Thus, even though as a model of prose The Lunar Trilogy came to be an evolutionary dead end of the Polish modernist novel, the same cannot be said about Polish literature at large; to this day it remains one of the most intriguing and continuously popular literary products of early modernism, one whose significance is yet to be fully recognized.

65. See, for example, Stanisław Lem, Zulawski's Silver Globe (de globe d'argent de Zulawski), trans. Elizabeth Kwasniewski, ed. RMP. Science Fiction Studies 12, no. 1 (1985), $1-5$. 